Medieval Studies, vol. 22, 2018 / Studia z Dziejów Średniowiecza, tom 22, 2018

\author{
Katarzyna Niemczyk \\ (University of Silesia in Katowice) \\ https://orcid.org/ 0000-0002-9656-3048
}

\title{
A few remarks about Bogdan the One-Eyed's matrimonial policies in the context of the conflict between Poland and Moldova in 1509
}

Keywords: Bogdan the One-Eyed,The Polish-Moldovan conflict, Elisabeth Jagiellon

The war between Poland and Moldova in 1509 was the continuation of a long-standing conflict between these two states. The origins of this problem lies in the time of reign of the Polish King Vladislaus Jagiellon, who needed money for his struggle with the Teutonic Order. He borrowed a sum of rubles (probably 4,000) from the ruler of Moldova, Peter I, and as a deposit, gave him, among other things, Pokutia. However, the Polish king did not return the money to the ruler of Moldova, and he did not give him Pokutia either. ${ }^{1}$ This is why, from that time on, Moldova tried to win this lost territory back. Despite many attempts to solve this problem, either by war or negotiations, it remained unresolved at the beginning of the sixteenth century. According to some historians, the reason for Bogdan's expedition in 1509 was the hope to marry Alexander's sister, Elisabeth Jagiellon. ${ }^{2}$

1 Besides Pokutia, Vladislaus Jagiellon gave as a deposit the land of Halych. See В. Розов, Укрански гралотьь, vol. 1, Київі 1928, по. 19; Материаль для истории взаилных отношений России, Польши, Молдавии, Валахии и Туриии в XIV-XVI вв. собр. В. А. Уляницким, Москва 1887, (further: V. Uljanickij), no. 3; A. Borzemski, 'Sprawa pokucka za Aleksandra,' Przeglad Powszechny, 24, 1889, no. 10, p. 172; I. Czamańska, Mołdawia $i$ Wołoszczyzna wobec Polski, Wegier i Turcji w XIV i XV wieku, Poznań 1996, p. 57, footnote 145; K. Niemczyk, 'Mołdawia Bogdana III Ślepego w polityce Aleksandra,' in: Jagiellonowie $i$ ich świat, eds. B. Czwojdrak, J. Sperka, P. Węcowski, Kraków 2015, p. 174.

2 J. Besala, Zygmunt Stary i Bona Sforza, Poznań 2012, p. 147; Z. Spieralski, 'Z dziejów wojen polsko-mołdawskich,' Studia i Materiaty do Historii Wojskowości, 11, 1965, part 1, p. 120. 
In this paper, I analyze reasons for this expedition, which affected the south-eastern borderlands of Poland. Consequently, I hope to be able to decide if there were any other reasons apart from the marriage arrangement that lay behind Bogdan's expedition.

Bogdan III came to power in Moldova in 1504 after death of his father, Stefan the Great. The beginning of Bogdan's reign was not easy. After the death of his great predecessor, both the opposition inside Moldova and foreign opponents tried to question his position. Also Poland, which was still in conflict with Moldova over Pokutia, tried to analyze the possibilities of winning this lost territory back. This is why the Polish envoy Bernard Goławinski was sent to Constantinople. His task was to investigate the Turkish reaction to a possible Polish attack on Moldova. He was also ordered to visit Walachia to encourage the local ruler to join the planned attack. ${ }^{3}$ Bogdan could not tolerate such behaviour. He was forced to face too many problems inside his country, so that he knew that a PolishTurkish-Wallachian alliance was too dangerous for him. He tried to find some allies to strengthen his own position, and to achieve this goal he wanted to make use of Pokutia. This territory had belonged to Moldova since 1502 when Stephan the Great conquered it. ${ }^{4}$ Bogdan, who counted on strengthening his position vis-à-vis his opponents inside Moldova as well as his foreign enemies (above all, Turkey), offered Pokutia to Poland in exchange for the possibility of marrying the sister of the Polish King Alexander. ${ }^{5}$ He thought that this would

3 Archiwum Główne Akt Dawnych (further: AGAD), Libri Legationum (further: LL) 2, k. 18-20; Akta Aleksandra króla polskiego, wielkiego księcia litewskiego (1501-1506), ed. F. Papée, Kraków 1927 (further: AAleks), no. 261, 262; Z. Spieralski, 'Z dziejów wojen...,' p. 106; I. Czamańska, Mołdawia i Wołoszczyzna wobec Polski, Węier i Turcji w XIV i XV wieku, Poznań 1996, p. 192; K. Niemczyk, 'Problem Pokucia, spornego terytorium polsko-mołdawskiego w końcu XV i początku XVI wieku,' Studia Historyczne, 57, 2014, no. 2, p. 167.

4 A. Jabłonowski, ‘Sprawy wołoskie za Jagiellonów. Akta i Listy. Akta Koronne,' in: Źródta dziejowe, vol. 10, Warszawa 1878, no. 23; Z. Spieralski, 'Z dziejów wojen...,' p. 83; L. Fac, 'Południowo-wschodni teatr działań wojennych w latach 1497-1509,' Rocznik Przemyski, 43, 2007, no. 1, pp. 67-68; M. Plewczyński, Wojny i wojskowość polska w XVI $w$., vol. 1, (1500-1548), Zabrze 2011, p. 150; K. Niemczyk, 'Problem Pokucia...,' p. 169.

5 AGAD, Metryka Koronna (further: MK) 21, k. 162; print: Matricularum Regni Poloniae Summaria, vol. 3, ed. T. Wierzbowski, Warszawa 1908 (further: MRPS III), no. 2048 (regest); AAleks, no 257; Z. Spieralski, 'Z dziejów wojen...,' pp. 105-108; K. Niemczyk, 'Problem Pokucia...', p. 167; eadem, 'Kamieniecki Geschlecht und seine Beziehungen zu Moldau am Ende des 15. und zu Beginn des 16. Jahrhunderts. Ein Überblick,' Codrul Cosminului, 20, 2014, no. 2, pp. 297-320; eadem, 'Mołdawia Bogdana III Ślepego...,' pp. 181-183. 
be a good way to win a strong all—Poland — and, by the way, he would solve the problem of a possible alliance between Poland and Turkey, an alliance that he was afraid of. From the Polish point of view, it was a very interesting proposal, but it was also dangerous, as it could result in a conflict with Turkey. Since Moldova was a territory within the orbit of Turkish interests, an alliance between Poland and Moldova could not be accepted by Turkey. On the other hand, if Poland rejected the alliance with Bogdan the One-Eyed, he would have desperately searched for support elsewhere, and that could have pushed him over to the Turkish side. That is why Bogdan's proposal was accepted by Alexander Jagiellon. The Polish king, who was occupied by the war against Moscow and was aware of the catastrophic condition of Polish army, as well as of the need to reform it, was very pleased with the possibility of winning Pokutia back without war. ${ }^{6}$ However, the mother of Princess Elisabeth, Elisabeth of Jagiellon (Elżbieta Rakuszanka), raised some strong objections against this project. She strongly rejected the possibility of her daughter's marrying the ruler of such a minor state as, in her opinion Moldova, was. Also the Princess Elisabeth was reluctant to marry the 'one-eyed barbarian', as she called Bogdan. ${ }^{7}$ The ruler of Moldova, who was very anxious about this position

6 It was very common in the time of Alexander's reign, that rittmeisters (Jan Kamieniecki among others) who were responsible for the defence of the south-east boarders of Poland complained to the king that they did not have enough knights. See Akta Aleksandra króla polskiego, wielkiego księcia litewskiego (1501-1506), ed. F. Papée, Kraków 1927 (further: AAleks), no. 93, 119, 120, 121, 123. Not only was there an insufficient number of knights, but they were also underpaid, which led to protests in 1504 . For more about these problems, see Z. Spieralski, 'Z dziejów wojen...,' pp. 91, 105; K. Niemczyk, 'Problem Pokucia...,' pp. 167 - 168; eadem, 'Mołdawia Bogdana III Ślepego...,' pp. 175 - 177, 182; eadem, Kamienieccy herbu Pilawa. Z dziejów kariery $i$ awansu szlachty polskiej do 1535/1536 roku, Katowice 2016, p. 188; F. Papée, Aleksander Jagiellończyk, Kraków 2006, pp. 97-98. The so-called 'pospolite ruszenie' usually needed so much time to be prepared for war that a Moldovan or Tatar army that attacked Polish territories had enough time to rob them and leave the country. See K. Niemczyk, 'Zagrożenie mołdawsko-tatarskie Rusi na przełomie XV/XVI wieku i jej wpływ na politykę wewnętrzną Polski,' in: Наукові праці Кал'янець-Подільського національного університету іл. І.Огієнка. Шсторичні науки, t. 24, На пошану профр. В.А.Смолія, Кам'янець-Подільський 2015, pp. 104-119; eadem, 'Red Ruthenia and the risk of Moldovan and Tatar attacks at the breakthrough of the $15^{\text {th }}$ and $16^{\text {th }}$ century,' in: Dialogul civilizatiilor. Interferente istorice se culturale/ Dialogue of civilisations. Historical and cultural interferences, ed. L. Zabolotnaja, Kiszyniów 2015, pp. 86-103.

B. Wapowski, Kroniki Bernarda Wapowskiego z Radochoniec, kantora katedr. krakowskiego: część ostatnia czasy podtugoszowskie obejmujaca (1480-1535), Kraków 1874 (further: Wapowski), pp. 62-63, 279; G. Ureche, Letopisetul tării Moldovei, ed. P.P. Panaitescu, Bucureşti 1958, p. 112, 126. 
of the queen, tried to win her over to this project. To achieve this, he attempted to talk first with Stanislaus of Chodcza, the queen's trusted man, asking him for intercession with Elisabeth of Jagiellon. That is why Bogdan sent his envoy Lukas Dracz to Stanislaus of Chodcza to invite him to Suceava, where further negotiations took place. ${ }^{8}$ This resulted in the mutual agreement of both sides. Bogdan the One-Eyed agreed to give back Pokutia to Poland for the hand of the king's sister, Elisabeth. ${ }^{9}$ As a result on 8 December 1505 , Bogdan's official envoy arrived at Alexander's court with the proposal of marriage.${ }^{10}$ In return, Polish envoys, Stanislaus of Chodcza, Nicolaus Firlej, and Bernard Wilczek, were sent to Moldova on 18 March $1506 .{ }^{11}$ The agreement between the two sides obliged Bogdan to give Pokutia back to Poland as the condition of receiving the hand of Elisabeth and this obligation was fulfilled by Bogdan.

${ }^{12}$ Unfortunately, due to Alexander's death (1506), the matter became complicated, and the marriage agreement was cancelled. However, Poland did not return Pokutia to Bogdan. Because of Polish failure to fulfil the agreement, Bogdan the One-Eyed, who felt cheated, decided to conquer Pokutia in September $1506 .{ }^{13}$ The Polish side hastily arranged an expedition under the command of Nicolaus Kamieniecki. ${ }^{14}$ The expedition was successful and Poland won Pokutia back; ${ }^{15}$ however, this was not the end of the war.

The Polish-Moldovan conflict started again in 1509, when Pope Julius II wanted to organize a crusade against Turkey. To realize his goal, he wished to weaken Turkey and undermine its alliances. In the first place, the pope began measures to win Moldova, as a possible Turkish ally, over to his side. In this case, he decided to use the unfilled

8 AGAD, LL 2, k. 48-49; AAleks, no. 294; K. Niemczyk, 'Problem Pokucia...,' p. 168; A. Borzemski, 'Sprawa pokucka...,' p. 378; Z. Spieralski, 'Z dziejów wojen...,' p. 108.

9 Acta et epistolae relationum Transsylvaniae Hungariaeque cum Moldavia et Valachia, vol. 1, ed. A. Veress, Budapest 1914, no. 63.

10 AGAD, MK 21, k. 314v - 315; print: MRPS III, no. 2519 (regest).

11 AAleks, no. 317.

12 AGAD, no. 5407; AAleks, no. 298, 317; K. Niemczyk, 'Problem Pokucia...,' p. 168; A. Borzemski, 'Sprawa pokucka...,' p. 379.

13 Z. Spieralski, 'Z dziejów wojen...,' p. 111.

14 AGAD, Archiwum Skarbu Koronnego, oddział 86, no. 6, k. 16, 17v, 18-19, 21, 23v, 25-25v, 28v-29v, 32v, 42v, 45-46, 47v. See also K. Niemczyk, 'Problem Pokucia...,' p. 169.

15 Z. Spieralski, 'Z dziejów wojen...,' p. 120; L. Fac, 'Południowo-wschodni teatr działań...,' p. 82; J. Marinescu, Bogdan III cel Orb 1504-1517, Bucureşti 1910, p. 44; K. Niemczyk, 'Problem Pokucia...,' p. 171. 
agreement between Poland and Moldova about Bogdan's marriage with Elisabeth. On 12 April 1509, he sent a breve to Sigismund I reminding him about his obligation to fulfil the agreement with Bogdan the One-Eyed. ${ }^{16}$ The king of Poland remained reluctant to follow the pope's orders as he feared that the marriage might badly affect relations with Turkey. Also his brother, the king of Hungary, Vladislaus, rejected the pope's order. ${ }^{17}$ Contrary to the view of historians to date, it seems also that Bogdan the One-Eyed did not have any hope of accomplishing the marriage project with Elisabeth, or for the success of Julius II's plans. Already in 1508-1509 Bogdan had made an effort to marry Ruxanda, the daughter of the ruler of Wallachia, Mihnea cel Rău. In a document, dated 7 September 1511, it is written that Duke Mihnea's widow Voica declared that her husband (she caled him vodă, whats mean the duke) bestowed gold and silver on his daughter as her marriage portion. As Mihnea fell from power in autumn 1509, the conclusion of the marriage agreement should have taken place before this time. ${ }^{18}$ The marriage could not take place immediately as, on 12 March 1510 in Sibiu, Mihnea cel Rău was murdered, ${ }^{19}$ and his family was in mourning. Then on 26 February 1511 Bogdan's mother died, ${ }^{20}$ and the preparations for the marriage had to be postponed again. However, the marriage contract was still binding, as in 1511

16 E. Hurmuzaki, Documente privitoare la istoria Românilor, (further: Hurmuzaki) vol. 2, part 2, Bucharest 1891, pp. 583-584, no. 465; J. Smołucha, Papiestwo a Polska $w$ latach 1484-1526. Kontakty dyplomatyczne na tle zagrożenia tureckiego, Kraków 1999, pp. 104-105; K. Baczkowski, 'Stosunki polsko-węgierskie w pierwszych latach panowania Zygmunta Starego 1507-1510,' in: Cracovia-Polonia-Europa:studia z dziejów średniowiecza ofiarowane Jerzemu Wyrozumskiemu w sześćdziesiata piata rocznice urodzin i czterdziestolecie pracy naukowej, ed. W. Bukowski, Kraków 1995, p. 571; J. Marinescu, Bogdan III cel Orb..., p. 39.

17 J. Smołucha, Papiestwo a Polska..., p. 105.

18 I. Bogdan, Documente şi regeste privitoare la relațiile Țării Rumâneşti cu Braşovul şi Ungaria în secolul XV şi XVI, Bucureşti 1902, pp. 143-144, no. 147; G.G. Tocilescu, 534 documente istorice slavo-române din Țara Românească şi Moldova privitoare la legăturile cu Ardealul, Bucharesti 1931, p. 216, no. 226; S. Gorovei, 'O controversă: „doamnele” lui Bogdan al IIIlea,' Studii şi Materiale de Istorie Medie, 27, 2009, pp.151-152; C. Rezachevici, 'Descendența nelegitimă a lui Vlad Țepeş: Mihneştii şi mitropolia bucureşteană de la Radu Vodă,' Arhiva Genealogică, 7 (12), 2000, no. 1-4, p. 229-238; idem, 'Dracea armaşul din Măneşti, soțul mamei lui Mihnea cel Rău, fiul nelegitim al lui Vlad Țepeş, şi moştenirea lăsată de el Mihneştilor,' Argessis, 14, 2005, pp. 315-331.

19 A. Lapedatu, 'Mihnea cel Rău şi ungurii 1508-1510,' Anuarul Institutului De Istorie Națională, 1 (1921-1922), pp. 70-71.

$20 \quad$ G. Ureche, Latopisetul..., p. 131; S. Gorovei, O controversă..., p. 152. 
Voica demanded from the town Braşov the return of gold-plated cups, which should have been used as part of her daughter's marriage portion. ${ }^{21}$ Finally, Bogdan married Ruxanda on 15 August $1513 .{ }^{22}$

According to some historians, the main goal of Bogdan the One-Eyed's expedition against Poland in 1509 was the implementation of the unfilled marriage agreement with Elisabeth of Jagiellon. ${ }^{23}$ It was also the official reason for this expedition which was announced by the Moldovan sidee. ${ }^{24}$ However, since Bogdan was striving at that time for the marriage with Ruxanda, there must have been a reason for his expedition in 1509 other than the hope to fulfil his former marriage contract.

The course of Bogdan's expedition seems to give us some suggestions and helps us to resolve this issue. In June 1509, the ruler of Moldova attacked both Pokutia and Podolia. ${ }^{25}$ On 27 June, Moldova's armies

${ }^{21}$ Hurmuzaki, vol. 15, part 1, p. 215, no. 387; Voica repeated her demands several times. She also directed these to Wladislaus, king of Hungary. Eventually she got twenty-three instead of twenty-four cups. See I. Bogdan, Documente şi regeste privitoare la relațiile Țării Rumâneşti cu Braşovul şi Ungaria în secolul XV şi XVI, Bucureşti 1902, p. 144; G.G. Tocilescu, 534 documente istorice slavo-române, pp. 215-217, no. 225, 226; S. Gorovei, $O$ controversă..., p. 152.

22 M. Costăchescu, Documentele moldoveneşti de la Bogdan voievod (1504-1517), Bucharesti 1940, pp. 367-369, no. 58; S. Nicolaescu, Documente slavo-române cu privire la relațiile Țării Româneşti şi Moldovei cu Ardealul în sec. XV şi XVI, Bucureşti 1905, pp. 13, 168; A.D. Xenopol, Istoria românilor din Dacia Traiană, Bucharesti 1986, p. 428; S. Gorovei, O controversă..., p. 147-148. Gorovei contradicts Alexandru Simon's opinion that Ruxanda was a Habsburg princess. See also J. Marinescu, Bogdan III cel Orb..., p. 114; C. Constantin, C. Giurescu, Istoria românilor, vol. 2, part 1, Bucharesti 1940, pp. 136, 146.

${ }^{23}$ J. Besala, Zygmunt Stary..., Poznań 2012, p. 147; Z. Spieralski, 'Z dziejów wojen...,' p. 120; However, Lucian Fac's point of view is that the expedition of Bogdan the One-Eyed against Poland was to take revenge ('Południowo-wschodni teatr działań...,' p. 83).

${ }_{24}$ It was the official reason for Bogdan the One-Eyed's expedition and in the peace treaty he renounced his right to marry Elisabeth see ATomic, vol. 1, no. 39; Dogiel, vol. 1, part. 2, pp. 606-610; Decjusz, pp. 29-30; A. Jabłonowski, 'Sprawy wołoskie za Jagiellonów...,' pp. 14-15; K. Baczkowski, 'Stosunki polsko-węgierskie w pierwszych latach panowania Zygmunta Starego 1507-1510,' in: Cracovia - Polonia - Europa, Kraków 1995, p. 573.

25 Decjusz, De Sigismundi regis temporibus liber, 1521, ed. W. Czermak, Kraków 1901 (further: Decjusz), p. 36; J. Smołucha, Papiestwo a Polska..., p. 105; M. Morka, Sztuka dworu Zygmunta I Starego. Treści polityczne i propagandowe, Warszawa 2006, p. 69; O. Cristea, 'Knocking at the enemy's gate: gesture of power of Bogdan III of Moldavia (1509),' in: Orient et Occident. Construction des identités en Europe médiévale, ed. L. Diaconu, Bucharest 2014, p. 155; L. Pilat, Intre Roma si Bizant. Societate si putere in Moldova (sec. XIV-XVI), Iasi 2008, pp. 224-227. 
started to storm Kamianets-Podilskyi. They were able to outwit Polish military intelligence, which had already crossed the Danube and gone towards Khotyn; however, the fortress of Kamianets-Podilskyi remained unconquered. ${ }^{26}$ So, Bogdan the One-Eyed decided to go towards Halych and try to seize it, but even this attempt ended without success, and Hlaych castle remained unconquered. The Moldovan armies then decided to go towards Lviv, their next goal. ${ }^{27}$ It is important to note that Bogdan the One-Eyed also attacked Rohatyn, a small village that belonged to the Chodecki family. The ruler of Moldova destroyed it, plundered it, and kidnapped a lot of inhabitants of this village, including the mother of Stanislaus of Chodcza, the man who was responsible for the unfulfilled marriage agreement between Bogdan the One-Eyed and Elisabeth Jagiellon, as a result of which Bogdan lost Pokutia, and his two brothers, Rafael and Peter, among others. ${ }^{28}$ Letopisetul tării Moldovei, written by Grigore Ureche, also states that additionally, during his attempt to conquer Lviv, Bogdan the One-Eyed hit the gate of the castle with his spear and stole the bell from the church in Rohatyn. He took this bell as his loot back to Suceava with him. ${ }^{29}$ The Romanian historian Ovidiu Cristea analyzes the symbolism of these actions. ${ }^{30}$ According to Cristea, both of Bogdan's actions-hitting the gate of the castle with his spear and the theft of the bell from the church in Rohatyn-were deliberate actions that were meant to demonstrate his power. In this way, Bogdan referred to well-known symbolism; ${ }^{31}$ he declared war on the entire Kingdom

26 J. Marinescu, Bogdan III cel Orb..., p. 41; J. Besala, Zygmunt Stary..., p. 147; A. Otetea, Istoria lumii în date, Bucharesti 1972, p. 563.

${ }_{27}$ O. Cristea, 'Knocking at the enemy's gate...', p. 155; L. Pilat, Intre Roma si Bizant..., pp. 224-227; J. Marinescu, Bogdan III cel Orb..., pp. 41-42.

28 'Cronica lui Macarie,' in: Cronicile slavo-române din secolele XV-XVI publicate de Ioan Bogdan, ed. P.P. Panaitescu, Bucureşti 1959, p. 91; Kronika polska Marcina Bielskiego nowo przez Joachima Bielskiego, syna jego wydana, Kraków 1597, p. 513; A. Nicolaou-Konnari, 'Diplomatics and Historiography: The Use of Documents in the Chronicle of Leontios Makhairas,' in: Diplomatics in the Eastern Mediterranean 1000-1500: Aspect of Cross-cultural Communication, eds. A.D. Beihammer, MG. Parani, C.D. Schabel, Leiden-Boston 2008, pp. 293-323.

29 G. Ureche, Letopisetul..., p. 129.

30 O. Cristea, 'Knocking at the enemy's gate...,' pp. 153-172; I have written more about this problem in my paper 'Chodeccy a wyprawa mołdawska z 1509 roku' (in print).

31 O. Cristea, 'Knocking at the enemy's gate...,' pp. 168-169. Cristea mentions many examples of hitting at castle gates with a spear. See L.V. Marvin, 'Men Famous in Combat and Battle: Common Soldiers and the Siege of Bruges,' Journal of Medieval History, 24, 1998, pp. 243-258; P. Stephenson, The Legend of Basil the Bulgar-Slayer, 
of Poland. ${ }^{32}$ I agree with Cristea's point of view, but I think that Bogdan's second action, the attack on Rohatyn and the theft of the bell from the church in Rohatyn, had another reason.

Contrary to some previously held opinions, it seems to me that the implementation of his unfulfilled marriage agreement with Elisabeth was only the official reason for Bogdan's expedition in 1509. In fact, the real reason was different. At that time, Bogdan the One-Eyed aspired to the hand of Ruxanda. It seems likely that he had lost any hope for fulfilling the agreement with the Poles. In my opinion, Bogdan the One-Eyed's expedition should be considered rather as an attempt to avenge himself on Poland, and above all, on Stanislaus of Chodcza, the owner of Rohatyn, because of the unfulfilled marriage agreement. Bogdan felt cheated, as he had trusted Stanislaus of Chodcza and had counted on his help. After the negotiations with the Polish king were successful, he returned Pokutia to Poland, and then suddenly the Polish side broke off the agreement, but they did not return Pokutia to Moldova. The ruler of Moldova had a right to feel cheated. That is why he attacked Rohatyn, kidnapped Chodecki's mother and his two brothers and stole the bell from the church. He took it to Suceava as a symbol of success. An additional reason, not without importance, was that the loss of Pokutia must have been very bitter for Moldova both financially and economically. In my view, Bogdan had no hope for his marriage with Elisabeth Jagiellon; it was only a pretext to attack Poland. The support from Pope Julius II helped him to make use of this unfulfilled agreement with Alexander Jagiellon and to try to conquer Pokutia and reclaim it. In reality, he wanted to avenge the insult he had suffered from the Polish side (and he especially blamed Stanislaus of Chodcza for this), and he seized the opportunity to recover Pokutia. The support from the pope gave him the pretext and the consent to attack Poland.

Bogdan the One-Eyed is commonly described by historians as an especially ugly person, with physical imperfections. ${ }^{33}$ The reason for this is the information offered by the chronicler Ureche, who

Cambridge University Press 2003, pp. 51-52; Documente privitoare la istoria Ardealului, Moldovei şi Țării-Româneşti, vol. 2, ed. A. Veress, Bucharesti 1929, p. 249; P. Buc, Dangereux rituel. De l'histoire médiévale aux sciences sociales, Paris 2003, passim; idem, The Dangers of Ritual: Between Early Medieval Texts and Social Scientific Theory, Princeton 2002, passim.

32 O. Cristea, 'Knocking at the enemy's gate...,' p.171.

33 Wapowski, pp. 62-63, 279; G. Ureche, Letopisetul..., p. 112, 126. 
revealed Bogdan's nickname 'Bogdan vodă cel Grozav şi Orbu' or 'Bogdan vodă cel Orb şi Grozav.' ${ }^{34}$ He goes on to call him 'grozav la față si orbu de un ochiu' (which means with terrifying appearance and blind in one eye). ${ }^{35}$ According to Romanian historians, Ureche wrote this because he was under the strong influence of Polish sources, and he wanted to use Bogdan's frightening appearance as a pretext for the rejection of the plan of his marriage to Elisabeth by the Polish side. This marks the beginning of black propaganda concerning the ruler of Moldova and of the story about his terrifying appearance. However, this was not the truth. For sure, Bogdan was not blind. Surely, he was a brave knight and took part in many battles. There is also no information in any sources about his alleged physical imperfections. It is supposed that he either could see with only one eye or that his sight was very weak. This could be a result of two things. First, he may have suffered from glaucoma in one eye, which seems to be confirmed by the fact that his descendants Bogdan and Alexander also suffered from this illness. ${ }^{36}$ A second option is that during a battle in 1497, he was hurt in his eye and that was the reason for his problem. In Romanian 'cel Grozav' does not mean 'with a terrifying appearance', but rather designates a man with exceptional physical features and moral precepts. ${ }^{37}$ Bogdan's impeccable appearance seems to be confirmed by his portrait, which we can see in the Orthodox church in Pătrăuți. In this portrait, we see no imperfections or defects. On the contrary, Bogdan seems to be handsome man (however, the portrait can also be perceived as an idealization of the ruler) ${ }^{38}$ As he did not see in one eye, he was called 'the Blind.' And that is why it is usual that today Bogdan is often called not 'The One-Eyed,' but 'The Blind One.' Another nickname for Bogdan is to found in a document from 1501-Choban. ${ }^{39}$ This story about Bogdan's blindness was rather the conscious procedure of chroniclers, who wanted to explain and justify why the Polish side did not fulfil the agreement with the ruler of Moldova and did not give him Elisabeth as a wife.

${ }^{34} \quad$ G. Ureche, Letopisetul..., pp. 112, 126.

35 Ibidem, p. 127.

36 P. Ştefănescu, Lumea văzută de medici, Bucharesti 1991, pp. 61-62.

37 V. Breban, Dicționar general al limbii române, vol. 1, Bucharesti 1992, p. 422.

38 I would like to cordially thank Professor Ilona Czamańska for permission to use a photograph of Bogdan the One-Eyed from the Orthodox Church in Pătrăuți.

39 Acta et epistolae relationum Transsylvaniae Hungariaeque cum Moldavia et Valachia, vol. 1, ed. A. Veress, Budapest 1914, pp. 54-57. 
Bogdan's expedition from the year 1509 is also negatively commented on by historians. They often charge Bogdan with being unfaithful, while the Polish King Sigismund I, who did not want to give permission for his sister's marriage with Bogdan the One-Eyed, is praised for his brotherly love towards Elisabeth. ${ }^{40}$ However, I would defend the ruler of Moldova. He concluded an agreement with Alexander Jagiellon, according to which he was allowed to marry Alexander's sister in exchange for giving Pokutia back to Poland. He fulfilled his part of the agreement and gave Pokutia back to Poland; he expected the Polish side to fulfil theirs and to give him Elizabeth's hand. So when this marriage plan was written off by Sigismund I, either because of his brotherly love, or because of political issues, which is definitely more probable, Poland should have returned Pokutia to Moldova. However, the Poles did not do this, which is why Bogdan the One-Eyed had a right to feel cheated. He decided to take justice with his own hand. I would not call Bogdan 'unfaithful' and would not blame him for the conflict of 1509. From the beginning of his reign, he was a supporter of peaceful policies towards Poland and wanted to solve the problem of Pokutia through negotiations. He did not wish for war. It is also incorrect to called him 'belligerent' or a 'dashing man,' as is the case in Polish historiography. ${ }^{41}$ In sources, he is often presented as 'demure like a small girl' and a 'chaste man.' ${ }^{42}$ This does not correspond with his image in today's historiography.

\footnotetext{
40 J. Besala, Zygmunt Stary..., pp. 147-149.

41 Ibidem, pp. 146-147.

42 The document from 7 December 1502 was published in Suceava, Călători străini despre Țările Române, vol. 1, Bucureşti 1970, p. 149.
} 